\title{
MT Steyn: 'n Moderne Christen-Afrikanerleier? MT Steyn: A modern Christian Afrikaner leader?
}

\author{
PJ STrauss \\ Navorsingsgenoot \\ Departement van Historiese en Konstruktiewe Teologie \\ Universiteit van die Vrystaat \\ Bloemfontein \\ Suid-Afrika \\ E-pos: straussp@ufs.ac.za
}

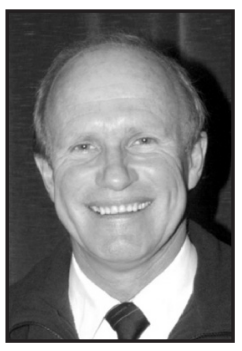

Piet Strauss

Pieter Johannes Strauss word in 1988 'n dosent in Ekklesiologie of Kerkgeskiedenis en Kerkreg aan sy alma mater, die Universiteit van die Vrystaat. Hy tree op 30 Junie 2015 af. Hy konsentreer op gereformeerde Kerkreg en kontemporêre Kerkgeskiedenis vanuit 'n reformatoriese hoek. Hy lewer meer as 150 artikels in geakkrediteerde akademiese tydskrifte en 'n aantal akademiese boeke. Onder laasgenoemde is die belangrikste waarskynlik Kerk en orde vandag (2010) en Kerkwees in die branding - die $N G$ Kerk in algemene sinodale verband 19942011 (2013). Strauss poog deurgaans om sy temas vanuit ' $n$ gereformeerde of reformatoriese oogpunt te benader.

Strauss was vanaf 1999-2003 en 2005-2008 moderator of voorsitter van die Vrystaatse Sinode van die NG Kerk. Vanaf 2007-2011 dien hy in dieselfde posisie by die Algemene Sinode. Verder is hy aktief op kulturele terrein. Hy was van 2001-2013 hoofleier van Die Voortrekkers en is vanaf 2010 die voorsitter van die Kommissie van die Nasionale Vrouemonument in Bloemfontein.
Pieter Johannes Strauss was appointed as a lecturer in Church Polity and Church History at his alma mater, the University of the Free State in 1988. He retired on 30 June 2015. Apart from more than 150 articles in accredited academic journals, he authored a number of books. In his scriptural academic work he focuses on a reformed Polity and contemporary (modern) Church History. Two of his main books are Church and order today (2010) and Being church in troubled times - the Dutch Reformed Church in the bond of its general Synod (2013). He uses a reformational approach in modern church history.

Strauss was moderator of the Free State Synod of the Dutch Reformed Church from 1999-2003 and again in 2005-2008. He served in the same capacity at the General Synod from 2007-2011. In addition, he is actively involved in cultural events. He was the national leader of the Afrikaans youth movement, Die Voortrekkers, from 2001-2013 and since 2010, he is the chairperson of the commission of the National Women's Memorial in Bloemfontein. 


\section{ABSTRACT}

\section{MT Steyn: A modern Christian Afrikaner leader?}

MT Steyn was the last president of the Republic of the Orange Free State (1896-1902), since his term as president coincided with the Anglo Boer War (1899-1902) in which the small republic, together with its sister state, the South African Republic (Zuid-Afrikaansche Republiek, ZAR), had to defend themselves against imminent invasion by Great Britain. His inspirational leadership during this war gave rise to nicknames such as "Afrikaner van die Afrikaners" (the outstanding Afrikaner) and "Siel van die Vryheidstryd" (the spiritual driving force behind the fight for freedom), simultaneously showing his close ties with the Afrikaner people.

This article takes a closer look at MT Steyn as an able leader of Christian Afrikaners in his time. It focuses on Steyn as an outspoken reformed Christian, his credo or expression of faith in God and his application of biblical truths to everyday life. His spontaneous identification with and leadership of the Afrikaner people are discussed with reference to his term as president, but also taking into consideration his conduct as an ex-president and community leader.

Steyn was born near the town of Winburg in the Free State on 2 October 1857, the first president to be born in the republic as such and educated within an Afrikaner farming community - according to him he was a "simple" son of a farmer ("'n gewone boerseun"), familiar with both "a horse and a gun". Given this kind of background Steyn's spiritual and emotional bond with the Afrikaner people was never doubted. It was simply accepted.

He was the political and spiritual leader - the real first citizen - of the Republic of the Orange Free State at the outbreak of the Anglo-Boer war in 1899. His reading of this momentous event was that the very existence of the Afrikaner people was at stake. In his opinion, imperialists such as the British High Commissioner in Southern Africa, Lord Alfred Milner, precipitated the Anglo-Boer War with the intent of discouraging the Afrikaner people in trying to resist the proposed expansion of the British Empire, which would cost them their freedom as citizens of an independent Boer republic.

Steyn spoke of the Triune God as our God who is three times holy. Apart from certain unpersonal names associated with the influence of the Enlightenment from 1750 onwards, he used scriptural or biblical names for the Lord. He accepted the beneficial effect of the providence of God in human life. His notion that nothing happened outside the will of the Lord, was shared by his fellow Afrikaners' unquestionable belief in the providence of God. Although the Boers could not explain it properly, they nevertheless believed in God's guiding while engaging in fierce battles with the English. Even the unimaginable suffering endured by women and children in concentration camps, where more than 34000 Afrikaner women and children reportedly died of unnatural causes, eventually resulted in the words, "Let thy will be done.." being included in the inscription on the Women's Memorial in 1913. It is important to note, here, that the by then ex-president Steyn was instrumental in having this particular inscription approved, thereby showing his ability to influence the opinion of his fellow Afrikaner people.

It should be clear that Steyn knew his people well enough to persuade them to follow his lead. Towards the end of the Anglo Boer War a well-known British enemy, Lord Kitchener, while in charge of the British troops in Southern Africa, remarked that Steyn had the ability to turn his people around in not accepting a peace treaty and, instead, to continue with the war. Undoubtedly, it was no easy decision for Steyn to surrender to the British, thereby accepting the reality that the Republic of the Orange Free State would cease to exist. At the end of the peace talks, his absence from signing the peace treaty due to serious illness, as far as he was 
concerned, could be ascribed to the providence of God. During the war Steyn often took the initiative of leading by example, thereby inspiring citizens of both the republics engaged in the war. According to his perspective the Afrikaners or Boers could physically lose the war, but still overcome the British emotionally and spiritually. However, should the Boers cowardly surrender to the British, they would lose both their self-esteem and self-respect.

A similar view was shared by Emily Hobhouse, the British Florence Nightingale who had endeavoured to alleviate the suffering of the Boer women and children in the concentration camps during the Anglo Boer War. In an address, read on her behalf at the opening of the Women's Memorial in Bloemfontein in 1913, she urged women and children to forgive the British aggressors, because, in her opinion, the Boers had gained the upper moral ground and could therefore afford forgiveness. This sentiment was echoed by Steyn in his reference to the triumphant martyrdom of the Afrikaner people, in particular the women and children. According to him they had lost the war but won the peace, and to his satisfaction they had also retained their self-esteem, Christian faith and proven values of life.

In Steyn's view, then, the struggle against British oppression could be justified as an attempt to uphold justice between the states of the world. As a Christian he opted for the structural equality of states, irrespective of their military power, material wealth or superior numbers. He chose to help the sister republic of the Free State, the ZAR, against the British, because as a Christian state, the Free State had to keep its promise, which was included in a treaty with the ZAR in 1889 and 1897. In the representative assembly of the Free State or the meeting of his "Volksraad" before the war, on 22 September 1899, he declared in public that although the Free State was a small and weak state, it was strong enough to keep its word.

Steyn saw in a republic with democratic customs the preferred way whereby a Christian Afrikaner state could be established. He chose a republic as the right of his people and one in which he as a Christian was willing to accommodate other cultures and languages. Already before his term as president, the Republic of the Free State was complimented as a model state. As a republican and a man with insight in the ways of the Afrikaner people, Steyn embraced the Free State as his homeland.

KEYWORDS: $\quad$ outstanding Afrikaner; confessing reformed Christian; first president born in the Republic of the Orange Free State; British imperialism; "Thy will be done ..." (“Uw wil geschiede ...")

TREFWOORDE: Afrikaner van die Afrikaners; belydende gereformeerde Christen; eerste seun van die land as president; Britse imperialisme; "Laat U wil geskied" ("Uw wil geschiede ...")

\section{OPSOMMING}

Die waardering vir president MT Steyn onder sy mense het weerklink in beskrywings waarmee hulle hom gekarakteriseer het, soos "Afrikaner van die Afrikaners" en "siel van die Vryheidstryd". Steyn (1896-1902) was die laaste president van die Republiek van die OranjeVrystaat, maar die eerste een wat in dié onafhanklike Boererepubliek gebore is. Omstanders kon sy belydenis van God Drie-enig as die Driemaal Heilige God uit sy eie mond hoor. Hy het sy taak, waaronder die Vrystaat se deelname aan die Anglo-Boereoorlog, in die geloof aangepak. Sy reaksie op probleme was gegrond op Christelike lewenswaarhede. Hoewel hy soms in onpersoonlike, onsydige terme na God verwys het, sou dit hom nie verhinder om die Bybel as gids vir die lewe te aanvaar nie.

Vanuit sy agtergrond as 'n Vrystaatse boerseun sou Steyn 'n spontane band met die Afrikaner en veral die Vrystaatse Afrikaner ontwikkel. Deur studie en opleiding as 'n Afrikaner 
uit Afrika in Nederland en Brittanje, asook deur sy vriendskap met bekende Engelse van Bloemfontein en sy werk as 'n Vrystaatse regter, sou Steyn ontwikkel in 'n moderne, belese en berese staatsman. Hierdie Vrystaatse president het gedurende sy ampstydperk (1896-1902) getoon dat hy deeglik op hoogte was van Suid-Afrikaanse en Westerse denkrigtings en dat hy sy eie posisie as Vrystater in hierdie opsig na binne en buite kon verantwoord.

Steyn se optrede as president op nasionale sowel as internasionale vlak is deurgaans gerig deur die beginsel van reg en geregtigheid. Hy was uitgesproke Afrikaans, maar met lewensruimte vir ander groepe. Daarby was hy 'n voorstander van die strukturele gelykwaardigheid van state, ongeag hulle mag of vermoë.

Steyn se sentrale lewenskompas is op die Vrouemonument aangebring: "Uw wil geschiede $\ldots "$

\section{INLEIDING}

In sy gesaghebbende studie, Die Afrikaners: 'n biografie (2003), wys Hermann Giliomee daarop dat die eerste premier van die Unie van Suid-Afrika, Louis Botha (1910-1918), na MT Steyn, die laaste president van die Republiek van die Oranje-Vrystaat (1896-1902), verwys het as die grootste Afrikaner van sy tyd (Giliomee 2003:360). Later tipeer Giliomee Steyn as die eerste moderne Afrikaner (Giliomee s.a.: 17). So plaas hy die vraag na Steyn as 'n moderne Afrikaner van die 19e en 20ste eeue ter tafel. Met hierdie stelling in gedagte word die tema van Steyn as moderne Afrikaner verder ontgin in hierdie artikel.

JD (Vader) Kestell, 'n Vrystaatse veldprediker in die Anglo-Boereoorlog (1899-1902) en goeie vriend van MT Steyn, ${ }^{1}$ noem hom in sy begrafnispreek in 1916 die kroon van die Afrikaners. Kestell preek uit Klaagliedere 5:6: “De Kroon onzes Hoofds is afgevallen.” In sy Vrystaatse Nederlands sê hy:

De Kroon van ons hoofd is afgevallen. Wij denken aan hem als mens, man Gods en groot vaderlander. 'n Afrikaner van die Afrikaners was hij ... Hij had 'n ruime blik over de grote wereld als man van ontwikkeling. Hij was vertrouwd met de wereldgeschiedenis ... In staatkunde kon hij zo raak zien²... Kosmopoliet was hij niet. Zijn wereld was ZuidAfrika. Wat Zuid-Afrika betreft, was de Vrijstaat hem alles. Heel Zuid-Afrika had toegang tot zijn hart, maar de Vrijstaat had de eerste plaats ... ontwikkeld, toch bleef hij in't huis type van de ongekunstelde Afrikaner. ${ }^{3}$ Hij schaarde zich tegen de sterken voor de zwakken. Zijn eerste toespraak was tegen de kapitalist. Dit gevoel voor't recht schaarde hem aan de zijde van vrouw en kind ...

1 Vir Kestell wat sedert 24 Oktober 1901 saam met Steyn op kommando beweeg, is Steyn sy "beminnelijken en volhardende president" (Kestell 1902:164, 172), vriend, geesgenoot en mentor (Strauss s.a.:11).

2 Kestell noem Steyn se geestelike krag, vergesigte oor die toekoms van die Afrikaner en insig in nasionale kwessies by geleentheid "verbluffend" (in Van Schoor 1992:342).

3 In antwoord op rekwisisies dat hy homself vir die amp van staatspresident in die Vrystaat beskikbaar stel, sê Steyn in 1895-1896: "Liefde tot die vaderland is elkeen aangebore ... Alles wat die Vrystaat betref, vind in my hart 'n weerklank, en vernaamlik wat die boerestand betref" (Van Schoor 1997:32). Die latere eerste minister van Suid-Afrika, DF Malan (1948-1954), vertel van sy besoeke in 1903 aan die Steyn-gesin in Reichenhall, Duitsland waar Steyn vir mediese behandeling was: “. .. die President ... is presies soos een van ons tipiese Afrikaanse boere. Daar is so min styfheid by hom as by die eenvoudigste Afrikaner" (aanhaling in Koorts 2014:62). 
Wij kunnen ook aan hem denken als man van God ... Hij geloofde dat God regeert. In de lotgevallen van het mensdom zag hij geen bloot noodlot. Het was geen onpersoonlike invloed: het was God zelf ... . (preek in Van der Merwe II 1921:354-355)

Wat uitstaan in Kestell se tipering van MT Steyn is dat hy hom beskou as 'n Afrikanerleier wat in God geglo het en as 'n ontwikkelde man, wat met 'n ruim blik oor die destydse groot wêreld, in sy hoedanigheid as Afrikanerleier in die Vrystaat en wyer, Bybelsgehoorsaam en na die eise van sy tyd sy taak wou uitvoer. Hy was inderwaarheid nie soseer 'n kind van sy tyd nie, maar vir sy tyd. In die konteks waarin Giliomee na MT Steyn as die eerste moderne Afrikaner verwys, vermeld hy sy voorkeur vir 'n "volwaardige" republikanisme waarin die grondwet ('n uitdrukking van die reg) "soewerein" is en waartoe die kiesers, by wyse van 'n "volkstemming", direkte inspraak het. Hierdie konstitusionalisme sou in die 20ste eeu via Steyn, Hertzog en andere die Suid-Afrikaanse politiek beïnvloed. As 'n eietydse, moderne Christen-Afrikaner sou Steyn hom as 'n volks- en politieke leier in die wêreld van sy tyd handhaaf (Giliomee s.a.:17).

Oor die omvattende regering van God in die geskape werklikheid bely MT Steyn volgens die Nederlandse Geloofsbelydenis, artikel 13, God-Drie-enig as die voorsienige God (NG Kerk-Uitgewers 1982:16). As die inisieerder van die Vrouemonument in Bloemfontein, is dit na alle waarskynlikheid te danke aan die oudpresident se inisiatief dat die samevattende sinnetjie op die voetstuk van hierdie Monument vir die dood van duisende vroue en kinders, lees: "Uw wil geschiede" (Van Schoor 1993:2). Resente navorsing dui op 34051 vroue en kinders wat in die Anglo-Boereoorlog in Britse konsentrasiekampe en elders gesterf het (Reynolds 2013:122; Raath 2012:13). Ter bevestiging van Kestell se waarneming van Steyn as 'n man van God, is " $U w$ wil geschiede" 'n geloofsbelydenis van Steyn in die voorsienigheid van God; 'n belydenis wat sy tipering van die lyding van Boerevroue en -kinders as 'n triomferende martelaarskap, uit 'n geloofsoogpunt verhelder (Strauss s.a.:17-20); 'n geloof wat Emily Hobhouse se voorgelese woorde aan die skare van ongeveer 20000 ten tye van die onthulling van die Monument in 1913 in perspektief plaas: “... forgive because you can afford it... because so only can you rise to full nobility of character and a broad and noble national life ..." (toespraak in Van Schoor 1993:30-34).

Met hulle waarnemings onderstreep Kestell en Giliomee die relevansie van hierdie ondersoek na MT Steyn as 'n moderne Christen-Afrikanerleier. Hulle menings kom op die volgende neer: MT Steyn as 'n moderne, ontwikkelde mens met 'n ruim blik was 'n gelowige Christen (Kestell), 'n oortuigde Afrikaner en 'n patriotiese Suid-Afrikaner (Kestell en Giliomee). Hy moes as 'n politieke, geestelike en kulturele leier antwoorde vind op die lewensvrae waarmee hy en sy mense met hulle Westerse leef- en politieke styl destyds in Suider-Afrika gekonfronteer is. Die Oranje-Vrystaat met Steyn as president was tydens die Anglo-Boereoorlog (1899-1902) in 'n oorlog gewikkel met die magtigste ryk wat die wêreld toe geken het: Brittanje (Vrystaatse Volksraadsnotule 22/09/ 1899: 23). 'n Oorlog wat hom in die destydse moderne Westerse wêreld afgespeel het én vereis het dat die Vrystaatse Republiek, met behulp van sy president se toekomsvisie, hom in hierdie wêreld moes handhaaf (Van Schoor 2009:253).

Steyn het in sy motivering sy man gestaan teenoor die Brits-imperialistiese magspolitiek van sy tyd - na sy mening was die uitbreek van die Anglo-Boereoorlog in 1899 'n ontkenning van die strukturele en volkeregtelike gelykheid van onafhanklike state. Brittanje het die (Christelike) volkeregtelike beginsel dat selfstandige state in 'n maatskapsfiguur mekaar se reg op onafhanklikheid erken en ondersteun, verontagsaam (Van der Merwe I 1921:142; Wessels 1977:205). 
In hierdie artikel word beoog om deur die fokus op MT Steyn se eietydse rol in SuidAfrika in die laat 19e vroeg 20ste eeu, sowel as sy Christen-Afrikanerwees, 'n aanvullende bydrae te lewer tot bestaande navorsing. Sy benadering van sy wêreld, sy lewensomvattende Christelike oortuigings én optrede asook die beeld van Steyn as 'n Afrikaner van die Afrikaners, word deurlopend belig. Die drie hoofsake van die tema kom deurgaans aan die orde: MT Steyn as 'n moderne (eietydse) Christen-Afrikanerleier. Enkele punte van kritiek ten spyt word geargumenteer dat MT Steyn inderdaad gesien kan word as 'n moderne Christen-Afrikanerleier.

\section{MT STEYN, ’N BOERSEUN}

MT Steyn is op 2 Oktober 1857 naby Winburg op die plaas Rietfontein gebore. Hy groei op as 'n "gewone boerseun" op Zuurfontein aan die Modderrivier, met 'n liefde vir 'n perd en 'n geweer. Sy middelbare skoolopleiding ondergaan hy aan Greykollege in Bloemfontein. Nadat hy op Zuurfontein geboer het, vertrek hy in Mei 1877 na Nederland vir opleiding aan die gimnasium in Deventer. In Januarie 1880 word hy toegelaat tot die Inner Temple in Londen en op 17 November 1882 tot die Engelse balie. Aan die einde van 1883 word hy in Kaapstad as advokaat aanvaar, in Januarie 1889 word hy aangestel as staatsprokureur en sewe maande later bevorder tot 'n strafregter van die Republiek van die Oranje-Vrystaat. Vanaf 1892-1896 is hy "eerste regter" op die Vrystaatse regbank. Regter Steyn toon 'n aanvoeling vir die Romeins-Hollandse reg in strafsake - soos te verwagte by Afrikanerregslui met 'n Hollandse opleiding. Sy vermoë as 'n regter en sy wellewende persoonlikheid maak hom gewild by die Vrystaatse Boere. Hulle beskou hom as 'n toekomstige gemeenskapsleier. In 1896 nomineer die Volksraad hom as president en die opvolger van oudpresident FW Reitz en hy word met 'n "oorweldigende meerderheid" deur die Vrystaatse burgers verkies (Kruger 1972:727-728).

Sy opvoeding in 'n Vrystaatse Afrikanergesin, sy regsopleiding in Brits-Europese verband en sy nabye kontak met bekende Engelse van Bloemfontein soos die Brands, Fichardts, Fischers en Frasers maak van hom 'n moderne, berese en belese jong Afrikaner: 'n man voortreflik toegerus vir die wêreld waarin hy hom bevind. Hy korrespondeer met sy verloofde, Tibbie Fraser, 'n NG predikantsdogter van Philippolis, in Engels. As 'n oortuigde Afrikaner én republikein ${ }^{4}$ vind hy polities-kultureel aansluiting by president Paul Kruger en sy ZuidAfrikaansche Republiek (ZAR), maar as 'n gematigde Vrystater het hy ook baie in gemeen met die tweetalige blanke gemeenskap van die Kaapkolonie (Giliomee s.a.:9). Hierdie agtergrond vind weerklank in sy siening van Suid-Afrika.

Ná sy dood word 'n huldeblyk aan hom voorgehou, wat op Senekal aan hom oorhandig sou word - hy sou op 16 Desember 1916 daar as spreker optree, maar sterf op 28 November 1916 in Bloemfontein, terwyl hy 'n byeenkoms van die Oranje Vrouevereniging toespreek (Van der Merwe II 1921:348-352). Hierdie huldeblyk kom van "Dogters en Seuns van SuidAfrika aan Sy Edelgestrenge MT Steyn". Die woorde "van Suid-Afrika" dui daarop dat dit jong Afrikaners is wat aan hom hulde bring. Hulle het destyds só oor hulself gepraat, terwyl die "Edelgestrenge" eerder op respek vir hom as persoon as op 'n eienskap van Steyn dui. Die bewoording van die huldeblyk skyn vanuit 'n huidige perspektief ietwat oordrewe en situasiegerig te wees. Tog bevestig hierdie huldeblyk Steyn se status as Christen-Afrikanerleier.

4 Van Schoor en Van Rooyen praat van die Afrikaner se "republikeinse tradisie en staatsvorming" wat verband hou met hierdie verskynsel in die Westerse beskawing én "vir 'n belangrike gedeelte selfstandig en uit eie krag uit die tradisionele lewenspraktyk en lewensbeskouing van die Afrikaner voortgespruit het” (Van Schoor en Van Rooyen 1960:1). 
Ons, seuns en dogters van die hele Afrikaanse Volk, wens ... U te laat verstaan dat U, as Vader van ons Vaderland, as Held van ons Volk, nog altyd ... die grote Volksvader bly, en die eerste plek in ons harte inneem ... U ... bly die ideale Afrikaner na wie ons onder die albestuur van onse God sal opsien as een van ons edelste helde ooit deur God aan ons gegee ... 'n Afrikaner sonder smet of blaam. (Met) opregte liefde en grote hoogagting van die Afrikanervolk. (Van der Merwe II 1921:353-354)

Agting vir Steyn kom ook van 'n teenstander in die Anglo-Boereoorlog, lord Kitchener. In 'n brief aan Brodrick, die Britse minister van oorlog, op 20 April 1902 - ongeveer 'n maand voor vredesluiting op 31 Mei 1902 tussen die Boerepublieke (die ZAR en die Vrystaatse Republiek) en Brittanje - skryf hierdie bevelvoerder van die Britse magte in Suid-Afrika dat die teenwoordigheid van Steyn as 'n bittereinder by die samesprekings die Britte se hoop op vrede nog 'n keer (soos ander kere, vgl. Strauss 2019:doi 10.4102/hts.v7514. 5200) kan verydel:

Steyn ... will make a patriotic speech at the meeting and turn them round. He is head and shoulders above the others, and has great influence, owing to his better education and ability. (woordeliks in Van der Merwe I 1921:VI) ${ }^{5}$

Met "owing to his better education and ability" erken Kitchener Steyn se vermoë om homself te laat geld in moderne politiek-georiënteerde situasies. Wat meer is, Kitchener se agting vir Steyn kom voor tydens 'n oorlog waarin verhoudinge tussen state teen die agtergrond van die moderne internasionale Westers-gedomineerde politiek ' $n$ beslissende rol speel.

Met sy aanduiding van Steyn as 'n ongekunstelde Afrikaner, bevestig Vader Kestell die stelling van 'n biograaf dat Steyn 'n "gewone boerseun" was; 'n seun wat uit die voorsienigheid van God wou leef en vir wie die woorde op die Vrouemonument, "Uw wil geschiede", sy lewenskoers verwoord. Hy is 'n Boerseun wat sy Christelike lewensbeskouing met die soli

$5 \quad$ In sy biografie voer Van Schoor aan dat dit vir Steyn bitter was om sy Transvaalse broers gereeld te berispe oor hulle "mismoedige vredesvoorstelle" en hulle te bemoedig om die stryd voort te sit. Die Britse Hoë Kommissaris in Suid-Afrika, lord Alfred Milner, het die standpunt oor Steyn as die uitstaande figuur aan Boerekant met Kitchener gedeel. Volgens Kitchener het hulle die ZAR so gespot omdat hy deur 'n kleiner staat "aan die neus gelei word", dat hy dink dat die ZAR sal deurdruk met die vrede in Mei 1902. Teenoor Steyn as bekende bittereinder sou die ZAR toestem tot 'n vrede waarna Kitchener klaarblyklik uitgesien het (Van Schoor 2009:212, 268; Van der Merwe I 1921:vi). NJ van der Merwe, 'n biograaf van Steyn, verwys na 'n bekende Vrystaatse offisier wat na aan Steyn in die oorlog was en beweer het dat die gereelde versoeke om vrede - en oorgawe - vanuit die ZAR president Steyn "se gesondheid gebreek en totaal uitgeput het" (Van der Merwe I 1921:v). 'n Ernstige spierverlamming het Steyn verhoed om enduit met die vredesonderhandelinge deur te gaan. By sy graf verklaar oudpresident Reitz dat Steyn vir meer as 14 jaar - tot met sy dood op 28 November 1916 - deur 'n liggaamlike en sielsmarteling geteister is voordat hy aan die voet van die Vrouemonument, die Monument wat hyself geïnisieer het, in "de boezem van het land dat hij so liefdgehad heeft", begrawe sou word (toespraak in Van der Merwe II 1921:357). Interessant genoeg is daar op die grafte van diegene wat aan die voet van die Monument begrawe is, net hulle name, geboorte- en sterfjaar aangebring: die fokus moes op die Monument bly (Van Schoor 1993:4,16-17). In 'n ander toespraak by Steyn se graf sê regterpresident Jacob de Villiers dat hy die oudpresident veral die laaste 14 jaar in die grootheid van sy karakter leer ken het. Steyn het sy geteisterde lot na siel en liggaam met waardigheid en grootheid gedra. Hy was die verpersoonliking van die beste eienskappe van sy volk (Van Schoor 2009:432): "eenvoudig, oprecht, getrouw, vaderlandsliewend, gematig maar daarbij onwrikbaar van beginsel, vol respect voor ... eigen volk zonder andere volkeren te minachten of te verkleineren" (Van der Merwe II 1921:360). Regter De Villiers beaam dus die trant van die adres van jong Afrikaners wat op Senekal voorgehou sou word en van dit wat tot dusver van Steyn gesê is. Dit gaan hier om eienskappe wat eie is/moet wees aan gelowige Afrikaners. 
Deo Gloria-beginsel (aan God alleen die eer) op sy hele lewe wou toepas: in sy persoon voor die Here, sy binnelandse sowel as buitelandse politiek en sy maatskaplik-kulturele lewe tussen sy mense (Strauss 1996: 560-570).

\section{MT STEYN OOR DIE HERE GOD}

MT Steyn se kennis en belewing van die Here word weerspieël in sy toesprake en verklarings. Hy bly deurgaans onwrikbaar in sy vertroue op God wat - volgens hom - die bestaan van die Afrikaner in sy voorsienigheid moontlik gemaak het en hierdie volk wat dus wettig bestaan, nie sal laat verdwyn nie. Vier dae ná die uitbreek van die Anglo-Boereoorlog, op 15 Oktober 1899 , bemoedig hy sy Vrystaatse burgers in 'n proklamasie, waaruit blyk dat vir die president as Christen-Afrikaner die Republieke se aanpak van die Anglo-Boereoorlog 'n saak van geloof is:

Hou goeie moed en staan pal in die geloof. Die Here God sal sy planne met ons volk nie laat verydel nie. Volhard dus in die stryd. Wanneer die nag op sy donkerste is, is die daeraad naby. (Van Schoor 1997:173)

Later, op 15 Augustus 1901, antwoord die bittereinder MT Steyn "te velde" op die verklaring van lord Kitchener dat die Boere moet oorgee. Volgens Steyn was die Boere nie die aggressors in die Anglo-Boereoorlog nie. Ná 'n uitgerekte aanloop van vyandelikhede moes hulle hulself verdedig. Oorlog uit selfverdediging is "een van de heiligste rechten van den mensch": 'n reg op voortbestaan wat in die twintigste eeu steeds Bybels verantwoord is, daarom "dat wij recht hebben op een rechtvaardige God te vertrouwen”. In geloofsvertroue gaan die Boere steeds al hulle kragte aanwend om "onzelven te verdedigen". Hulle het die oorlog teen die Britse oormag in die geloof begin en sal dit in die geloof voortsit (Steyn se brief in De Wet 1959:101).

Opmerklik gebruik die president dikwels 'n Ou Testamentiese naam vir die Here: die Here God (in Van Schoor 1997:173); 'n naam wat getuig van 'n persoonlike verbintenis, innigheid en liefdevolle respek. Hierdie respek verbreed as hy sy burgers in die naam van die "Driemaal Heilige God" aanspoor om te volhard in 'n regverdige stryd voor God: die "heilige stryd vir Vryheid en Reg", wat hulle teen Brittanje as aggressor en imperialis stry. Om sy woorde te beklemtoon en meer gesag daaraan te gee, gebruik die president 'n gelaaide naam vir die Here: "die Driemaal Heilige God" (in Van Schoor 1997:176). Daarmee sinspeel hy op die Drie-enige God in sy sondelose goddelikheid. Hierdie Naam, anders as "Here God", kom nie net so uit die Bybel nie, maar vir Steyn is dit 'n vertolking wat belydenisbegrond én ryk aan geloofsinsig is. Van die Driemaal Heilige God is die sondige, tydgebonde mens afhanklik vir 'n gehoorsame lewe, sy toekoms en daaglikse brood. By geleentheid van die herdenking van die vyftigjarige bestaan van die NG Kerk Bloemfontein en die hoeksteenlegging van hulle Sinodale Gedenksaal, gebruik Steyn die Hebreeuse "Ebenhaeser": tot hiertoe het die Here ons gehelp. Sy wens: mag die Here die kerk só help dat dit 'n rusplaas vir die vermoeides sal wees (Van Schoor 1997:44; NGK Jaarboek 2012:203).

Téénoor hierdie persoonlike omgang met die Here én Kestell se opmerking van geen onpersoonlike elemente in Steyn se verstaan van God nie, gebruik MT Steyn soms wel onpersoonlike begrippe vir God. Hy druk sy verwysing na die Here uit in goddelike eienskappe wat, gevoed deur die Verligting van 1750, vir sekere moderne mense aanvaarbaar is; die Verligting of humanisme wat van die rede, aanvoeling en belewing van die mens 'n mensgesentreerde norm vir waarheid maak. In die Vrystaatse Volksraad wens die president op 21 September 1899 dat die "Almagtige" aan hulle die krag sal gee om die regte besluite in 
belang van vrede en ons "dierbare Staat" te neem (Van Schoor 1997:155). Voor die OrangiaUniekongres, 'n politieke party (1906-1911) in die Oranjerivierkolonie, skryf Steyn in 1910 die ontstaan van die Unie van Suid-Afrika toe aan 'n onpersoonlike konsep, naamlik die "Almagtige". Die rede: die Almagtige beskik alles en is daarom almagtig - as 'n onsydige krag of ongespesifiseerde almagtige (Oberholster \& Van Schoor s.a.:168). By die Nasionale Konvensie wat die Unie voorafgaan, praat Steyn van 'n keuse vir die hoofstad van die Unie wat deur "die omstandighede of noodlot - noem dit wat u wil, ek praat liefs van die Voorsienigheid ..." beslis sal word. Hy praat van die Voorsienigheid en gebruik die begrip asof op 'n vergelykbare vlak met die onpersoonlike noodlot (Oberholster \& Van Schoor s.a.:159). In 1895 sê Steyn dat die onafhanklikheid van die Vrystaat én die volkswees van die Afrikaners 'n kleinood is wat aan hulle "door de Voorzienigheid geschonken is" (De Gouvernements Courant OVS 27:12:1895:1; Strauss 1996:560). Steyn is volgens alle aanduidings 'n ChristenAfrikaner, maar gebruik soms name vir God-Drie-enig en sy beskikking van alles, wat vreemd is aan die Skrif en gereformeerde belydenis.

\section{MT STEYN OOR SY EIE MENSE}

Gemeet aan hoe ander hom beleef het, was Steyn 'n "gewone boerseun" en 'n Vrystaatse Afrikaner. In sy begrafnispreek noem 'n herderlike Vader Kestell vir Steyn 'n ongekunstelde Afrikaner; 'n Afrikaner “tot" wie se hart die hele Suid-Afrika toegang gehad het, maar waarin die Vrystaat - Steyn se “dierbare ... klein Gemeene Best” (in Van Schoor 1997:32) - eerste was (preek in Van der Merwe II 1921:354-355).

Schoeman raak een van Steyn se eienskappe as 'n boerseun aan as hy 'n seun van oudpresident Reitz aanhaal wat hom bestempel as "a burly, heavily bearded man, not brilliant, but possessed of a dogged courage” (Schoeman 1983:17).

Vir 'n eietydsgerigte Steyn was die bestaan van die Afrikaner gegrond op sy reg op 'n eie kultuur en 'n gevolg van die staat se handhawing van gelyke taalregte vir Afrikaans- en Engelssprekendes: die staat wat die regsaspekte van die Afrikaner se taal en volkswees op staatsbodem syns insiens prinsipieel móés beveilig - in die Vrystaat én die Unie van SuidAfrika. ${ }^{6}$ Oberholster en Van Schoor bevind dat Steyn se oorheersende wens vir een staatkundige Suid-Afrika die ideaal van 'n Afrikanervolk onder 'n Republikeinse vlag van die Kaap tot die Limpopo behels het. Die defensiewe politieke verbond van die Oranje-Vrystaat met die ZAR in 1897 wou nie die res uitdaag en wantroue in die Afrikaner skep nie, maar 'n beweging begin wat die hele Suid-Afrika insluit; 'n inklusiewe benadering wat vertroue in die bestaan van die Afrikaner inboesem én daarvoor ruimte laat. Steyn wou uit 'n moderne visie op die staat wat moet sorg vir die regsbelange van almal in Suid-Afrika, die begrip algemene regsbelang as ' $n$ norm vir die beslegting van binnelandse sake invoer. Die Britse beleid van verengelsing in die Vrystaat en Transvaal ná 1902 het die kulturele minderwaardigheid van die Afrikaner

6 In 1899 verklaar die Vrystaatse president dat die Here in sy voorsienigheid aan die Afrikaner sy bestaansreg gegee het. Milner se oorlog of die Anglo-Boereoorlog gaan nie oor uitlanderstemreg nie, maar die bestaan van die Afrikanervolk (Vrystaatse Volksraadsnotule 22:09:1899:23; Van der Merwe I 1921:255). In sy afdeling onder die titel "Milner's war", wys Pakenham op 'n brief van Milner aan Roberts onder datum 06/06/1899, 'n brief net ná die mislukte vredeskonferensie van Mei-Junie 1899 in Bloemfontein, waarin Milner erken: "I precipitated the crisis, which was inevitable, before it was too late. It is not very agreeable, and in many eyes not a very creditable piece of business to have been largely instrumental in bringing about a big war ..." (Pakenham 1979:115). 
beoog en die regsbalans - in belang van almal op staatsbodem - in die gemeenskap versteur (Oberholster \& Van Schoor s.a.:11-13).

Steyn as die bittereinder der bittereinders was seker daarvan dat die kleiner Boerepublieke dit op die lang duur nie sal volhou teen Brittanje as wêreldmoondheid nie. Tog word hy as Vrystaatse president deur sy aanwesigheid en aansporing van die Boere op die slagveld die simbool van voortgesette weerstand. Omdat die stryd van die Republieke uit selfverdediging teen die Britse imperialisme met sy militêre aggressie en ewolusionistiese konsep van mag is reg ( "the survival of the fittest"), spruit, kan die volhardende weerstand van die Boere, so glo Steyn, tot 'n morele oorwinning lei. Die Boere kan die oorlog verloor, maar die vrede wen. In plaas van in 'n gees van minderwaardigheid moet hulle in 'n gees van morele meerderwaardigheid uit die oorlog kom. Die oorlog moet die Afrikaner inspireer en nie verneder nie (Oberholster \& Van Schoor s.a.:14-15). ${ }^{7}$

Dat hierdie visie van MT Steyn waar geword het, blyk uit spreuke op monumente wat sedertdien deur die Anglo-Boereoorlog en 'n ontwaakte kulturele bewussyn by die Afrikaner ná die oorlog geïnspireer is: "Uw wil geschiede", "Voor, vrijheid, volk en vaderland" en "Gewond maar onoorwonne” (Van Schoor 1992:141; 1993:2-3; Strauss s.a.:4). Boonop het die oudpresident in sy openingsrede by die kongres van die Orangia-Unie in Mei 1906 die "wedergeboorte van die Afrikaner se politieke bewussyn op so 'n kragtige wyse" gestel "dat niemand ... oor die ... strewe daarvan in twyfel gelaat is nie" (Oberholster \& Van Schoor s.a.:135). Milner se imperialistiese Anglo-Boereoorlog, volgens Steyn, het 'n "gees van eie waarde en ... broederskap onder ... Afrikaners" geskep en "sy wanregering daarna het hierdie besef ... versterk" (Oberholster \& Van Schoor s.a.:145). Op hierdie punt het Steyn die Britse politikus Campbell-Bannerman aangehaal wat gesê het dat voorspoed, vrede en geluk in SuidAfrika slegs moontlik is deur regverdigheid aan almal. Ironies - vir die Britse imperialis Milner - het Campbell-Bannerman bygevoeg: "Lord Milner had inflicted the greatest injury on the Empire after the loss of America” (Van Schoor 2009:319).

Met sodanige volkeregtelike argumente was Steyn in sy tyd 'n pleitbesorger vir die reg van sy mense. As 'n ontwikkelde, moderne Afrikaner kon hy daarvoor uit die Britse politiek aanhaal.

Dit is al wat ons vra. Ons vra geen gunste of voorregte bo ons Engelse medeburgers nie. Ons het vroeër goed met hulle oor die weg gekom en sal dit nou ook weer doen. Ons vra alleen: behandel ons regverdig. As dit ... nie geskied na al die ... beloftes nie, sê ek met al die erns wat in my is dat die laaste dwaling nog die grootste van almal sal wees. (Oberholster \& Van Schoor s.a.:145-146)

Op sy proklamasie of papierbom (die naam wat die Boere dié soort geskrif gegee het) van 7 Augustus 1901, waarin lord Kitchener die Boere aanraai om oor te gee, antwoord Steyn, soos aangetoon, op 15 Augustus 1901 (Van der Merwe II 1921:26). Volgens Steyn moes die Boere

\footnotetext{
7 Die Anglo-Boereoorlog sou tot 'n geestelike en nasionale ontwaking onder Afrikaners lei: 'n ontwaking met politieke, taal-kulturele en sosiaal-kerklike gevolge; 'n ontwaking waarin die geestelike navolgers van Steyn as die bittereinders die hef in die hand gehad het en in die 20ste eeu suksesse sou behaal waarvan die ontstaan van die huidige Republiek van Suid-Afrika in 1961 een is (Loe 1985:210; Strauss 2015:40-49). Steyn het dikwels na sy ervaring op 6 Junie 1901 by Graspan naby Reitz verwys waar die bloed van 'n gesneuwelde Kolonialer, Vrystater en Transvaler ineengevloei het. Vir hom was dit simbolies van 'n verenigde Suid-Afrika, omdat geen mens die bloed meer kon skei nie. Steyn wou ook nie daarvan weet dat die Vrystaat die Kaapse Rebelle by die saampraat oor vrede in die steek laat nie (Van Schoor 2009:329).
} 
die swaard van die Britse imperialiste op hulle kele wegstoot. Daarom "dat wij recht hebben op een rechtvaardigen God te vertrouwen". ${ }^{8}$ Kitchener se gesag in die Republieke strek net sover as wat sy kanonne skiet. 'n Oorgawe deur die Boere in Augustus 1901 sal tot selfveragting lei (brief in De Wet 1959:101). Meer as 80 jaar later beaam Loe die argument: "the Boer War had guaranteed that Afrikaner nationalism would survive ..." (Loe 1985:210).

In die aanloop tot die Anglo-Boereoorlog wys Steyn op die twee Boererepublieke as die plekke waar die gees van die Afrikaner - wetlik en reëel - lewend gehou word (Van der Merwe I 1921:253). ${ }^{9}$ Die Britse imperialis wil die Afrikaner vernietig, omdat sy staatkundige vryheid in eersgenoemde se pad van uitbreiding en oorheersing staan (Van Schoor 1997:167). Volgens Steyn moet die Vrystaat as 'n Boererepubliek sy politieke verbond met die ZAR in 1889 soos hersien in 1897, nakom, want kan een Afrikaner eenkant staan as 'n ander vir Afrika sterf? (Vrystaatse Volksraadsnotule 22:09:1899: 23; Van der Merwe I 1921:256). Boonop moes die imperialis Milner na afloop van die Anglo-Boereoorlog ontdek dat Afrikaners 90\% van die blanke bevolking van die Vrystaat uitmaak. Die Vrystaat was 'n Boererepubliek waarin Engelssprekendes met hulle kultuur ook welkom was. Hierdie Republiek het - anders as Milnerisme - respek betoon teenoor 'n kultuur wat in beduidende getalle by hom aanwesig was (Oberholster \& Van Schoor s.a.:143). ${ }^{10}$ Hertzog se Orangia-Unie van 1906, soos gesteun deur Steyn, ${ }^{11}$ wou almal betrek: ryk en arm, pro-Britse werkers en pro-Boere bittereinders,

$8 \quad$ Ná die inname van Pretoria deur die Britse leër wys Steyn op 5 Junie 1900 (Blake 2010:45-48) daarop dat die grondbeginsel van 'n beskaafde volkereg die aanvaarding van die strukturele gelykheid van state, afgesien van hulle grootte of mag, is. Vir Christelik-beskaafde state is mag nie noodwendig reg of altyd reg nie. Die ideale figuur vir tussenstaatlike verhoudinge is ' $\mathrm{n}$ maatskapsfiguur van strukturele gelykheid (Wessels 1977:205).

9 Steyn sê op 27 September 1899 in die Vrystaatse Volksraad dat Brittanje "de twee Republieken, waar de Afrikander geest levend wordt gehouden, (wil) uitwisschen, en zoodoende het Afrikander volk vernietigen en indien mogelijk uitroeien". Die afgelope oorwinning van die Afrikanerbond (Steyn praat van "partij" in plaas van bond) in die verkiesing van die Kaapkolonie, stimuleer hierdie dryfveer. Die Afrikanergees staan direk teenoor die ideaal van 'n Britse imperialisme in Suider-Afrika (toespraak in Van der Merwe I 1921:253). Steyn impliseer dat die voortbestaan van die Afrikaner as 'n volk nie aan die inisiatief van 'n sekere staatsowerheid toegedig kan word nie, maar dat 'n staatsowerheid sy taak as owerheid teenoor 'n kultuurgemeenskap moet nakom deur die regsruimte daar te stel wat dit vir hierdie gemeenskap makliker sal maak om sy reg van bestaan op sy eie te handhaaf.

10 Hoewel bestaande literatuur oor die uitsprake van Steyn toon dat ander sake soos die verhouding tussen Boer en Brit, die taalregte van die Afrikaner in die Republiek van die Oranje-Vrystaat en die Unie van Suid-Afrika en die omvattende ontwikkeling van sy eie mense in sy tyd die groot sake was waaraan hy moes aandag gee, het die oudpresident by geleentheid sy begrip vir ander groepe in Suider-Afrika ook laat blyk. In 'n uitleg van die voorgestelde grondwet van die Unie van 1910 sê Steyn in 1909 dat die posisie van Kleurlingstemreg in die vier kolonies by hulle opname in die Unie gehandhaaf moet word, omdat hy "geroepe is" om die blanke rasse nou te verenig en nie kan toelaat dat die "kleurlingkwessie" in die weg daarvan staan nie. Anders as in die Kaapkolonie waar die kleurling al vir vyftig jaar kan stem, het die Vrystaat, Transvaal en Natal aangedui dat hulle dit nie sal toelaat nie. Óf die Nasionale Konvensie wat hierdie eenheid reël, moet stemreg vir die kleurling op die laaste drie afdwing, óf hulle moet die kleurling verontreg wat 'n seën van die Here verwag (Oberholzer \& Van Schoor s.a.:163). Steyn het 'n baie goeie vertrouensverhouding met sy agterryer of "sy ou jong", Ruiter, gehad (Oberholzer \& Van Schoor sa:168). Uit hierdie gebeure blyk dit dat die oudpresident soms prioriteite daarop nagehou het wat in praktyk meegebring het dat hy sekere "kleiner" (vir hom) probleme oorgesien of uitgestel het.

11 Steyn se eggenoot Tibbie het hom aangespreek omdat hy ná 1902 "president" as die naam waarop Afrikaners hom aangespreek het, wou vermy. Volgens haar sou hulle hom tot in sy laaste lewensuur as hulle president beskou. Hertzog het hom ook daarop gewys dat Afrikaners hom ná die vrede in 1902 nog nooit anders as hulle president aangespreek het nie (Van Schoor 2009:309). 
"takhare" en geskooldes. In die Engelse pers in Suid-Afrika is Afrikaners wat gelyke taalregte eis, gebrandmerk as "racialists"; mense wat kwansuis 'n wig sou indryf tussen die Engelse en Afrikaanse "rasse"12 (Giliomee 2003:273-274). By die kongres van die Orangia-Unie in Maart 1910 laat MT Steyn hom skerp hieroor uit. As rassisme beteken dat die een "ras" die ander onderdruk en sy regte ontken, is dit verfoeilik, maar as dit gaan om die natuurlike liefde van iemand vir sy volk, taal en tradisies, sê die oudpresident: "Ek is 'n 'racialist"'. 'n Gedenasionaliseerde Afrikaner is 'n armsalige skepsel, sonder krag of rugmurg. Hier voeg die gewone boerseun by: "Hy is soos 'n vlermuis wat nie deur die muise erken word nie en deur die voëls verag word" (Oberholster \& Van Schoor s.a.:170).

Voor die Nasionale Konvensie wat 'n konsepgrondwet vir die Unie van Suid-Afrika (1910-1961) moes opstel, het MT Steyn die rasse-etiket verwerp. Die erkenning in Suid-Afrika van Hollands naas Engels as 'n amptelike taal was - wat hom betref - nie 'n guns nie, maar "ons reg". Vir hom was Nederlands die oudste Europese taal in Suid-Afrika en "op een of ander tyd in die verlede die offisiële taal van al die Kolonies" (Oberholster \& Van Schoor s.a.: 156). Uit 'n regshistoriese hoek moes Hollands ook gelykgestel word met Engels as amptelike taal in Suid-Afrika. Giliomee wys daarop dat die Nasionale Konvensie MT Steyn se betoog aanvaar en die effektiewe gelykheid van die tale met voorbeelde uit die staatspraktyk in artikel 137 van die nuwe grondwet vir die Unie ingeskryf het. Het dit nie gebeur nie, kon Afrikaners onttrek het uit die beoogde Unie en het die Konvensie misluk (Giliomee 2003:276). Oberholster en Van Schoor kom op grond van die getuienis van afgevaardigdes na die Konvensie tot die gevolgtrekking dat Steyn se pleidooi vir artikel 137 tot hulle persoonlike aanvaarding daarvan gelei het. Om hom verstaanbaar aan almal oor te dra, het die oudpresident Engels gepraat. Die kern van sy betoog was dat die gelykheid van die Afrikaanse en Engelse rasse moet lei tot versoening en bewys dat die Anglo-Boereoorlog met al sy ellende nie verniet was nie. Vir Steyn was die gelykheid van die twee tale 'n reg, versiende en eietyds. Die opneem van taalregte in die grondwet neem dit uit die praktiese politiek en verhoed dat politieke verdelings langs Afrikaans-Engelse "rasselyne" loop (Oberholster \& Van Schoor sa:156).

Steyn se telegram aan die studentetaalfees in Kaapstad in 1913 word wyd bekend: "Die taal van die veroweraar in die mond van die verowerde is die taal van slawe" (Van Schoor 1997:43). Daarmee het hierdie gewone boerseun vanuit sy agtergrond as boerseun en sy oortuigings as 'n bittereinder, 'n kernbydrae tot die ontstaan en inkleding van die Unie van Suid-Afrika gelewer. ${ }^{13}$

\section{MT STEYN OOR REG EN GEREGTIGHEID IN DIE VOLKEREG}

Steyn se prinsipiële keuse vir reg en geregtigheid aan almal betrokke - binnelands sowel as buitelands - blyk ook uit sy motivering vir die Republiek van die Oranje-Vrystaat om aan die kant van die ZAR as sy bondgenoot by die Anglo-Boereoorlog betrokke te raak. Die ultimatum van die ZAR aan Brittanje op Maandag 9 Oktober 1899, wat op Woensdag 11 Oktober sou verstryk, en die eis dat die Britte hulle sametrekking van troepe op die grense van die Republieke

12 Die term "ras" slaan hier op die destydse betekenis daarvan - nie as onderskeid tussen wit, swart en bruin rasse nie, maar wel as onderskeid tussen verskillende tale binne 'n wit rassegroep.

13 In 'n huldeblyk aan die Hollands-Afrikaanse taal- en onderwysstryder, JBM Hertzog, in 1911 in Bloemfontein waar Steyn die woord voer, sê hy dat die gelykberegtiging van Hollands in SuidAfrika verbind word aan die Afrikaner se geestelike en ekonomiese belange, sy selfrespek en volkswees (Oberholzer \& Van Schoor s.a.:126). 
staak, lei tot 'n sielsworsteling by Steyn. Sondag 8 Oktober bring hy alleen in die veld op sy plaas Onze Rust naby Bloemfontein deur. Sy vrou, Tibbie, wat glo dat hy merendeels in gebed was, meld dat hy daarna met die vaste oortuiging huis toe gekom het dat hy moet veg vir reg en geregtigheid (Meintjes 1969:104). Hierna sou hy as bittereinder saam met die burgers tot die einde van die Anglo-Boereoorlog in 1902 volhard. ${ }^{14}$ Teen die einde van die oorlog het hy 'n ernstige spierverlamming opgedoen wat sy gesondheid permanent geknak het (Meintjes 1969:210).

Die kern van Steyn se benadering tot die oorlog is gekenmerk deur sy verstaan van geregtigheid as 'n norm vir die situasie en sy eenvoud van geloof, optrede en verhoudinge. Hoewel heldeverering nie uitgesluit kan word nie, gebruik sy skoonseun NJ van der Merwe voorbeelde van ander om Steyn se optrede onder die burgers te beskryf. Hy praat van 'n "ongekunstelde eenvoud, kalme vasberadenheid, opgeruimdheid van hart in die donkerste ure, grootse selfopoffering en onwrikbare vertroue op God" (Van der Merwe II 1921:34vv). Hiermee bevestig hy dat Steyn 'n konsekwente Christen-Afrikanerleier in 'n veeleisende situasie was; dat hy 'n staatsman van sy woord was en as politieke leier die daad by die woord gevoeg het.

In sy reaksie op die Jameson-inval in die ZAR teen einde 1895, het Steyn in 1896 as nuut beëdigde president van die Vrystaatse Republiek ook blyke van sy Christelike benadering tot die volkereg gegee. Hy was oortuig daarvan dat hierdie militêre ingrepe (wat die ZAR in die kiem gesmoor het) in die huishouding van 'n onafhanklike staat 'n oortreding van die eerste beginsels van die volkereg en 'n misdaad was (MT Steyn soos gedikteer aan Tibbie Steyn en opgeneem in Van der Merwe I 1921:142). Selfverdediging teen sulke vergrype is 'n reg wat die Hére aan 'n staat gee (Van der Merwe II 1921:5). ${ }^{15}$ Steyn het leuens deur Rhodes in die steun van laasgenoemde aan Jameson uitgewys en die mislukking van die inval aan 'n stelling in die Bybel toegeskryf: "Wee u die trouwelooslik handelt, want tegen u zal trouwelooslik gehandeld worden" (Steyn in Van der Merwe 1 1921:122-123). Die Vrystaatse president het die "rassehaat" wat die "ellendige vrijbuiter ... ons in het hart jaagt" afgewys (toespraak by sy inhuldiging in Van der Merwe I 1921:72-75). Mag die republikeinse "Afrikaner" - die begrip "Afrikaner" word geïmpliseer in die konteks - volhard met sy Bybel én geweer (Strauss 1996:562).

Sonder om 'n grondige ontleding te gee, het MT Steyn hiermee die beginsel van nieinmenging en eerbied vir die landsgrense van ander in vreedsame naasbestaan, as Christelike norme vir die verkeer tussen state uitgewys. In sy motiveringsrede in die Volksraad op 22 September 1899 vir die Vrystaat om sy politieke verbond met die ZAR na te kom en aan die kant van die ZAR tot 'n moontlike Anglo-Boereoorlog toe te tree, werk hy met dieselfde beginsel. Vir hom gaan dit om 'n maatskapsverhouding tussen struktureel gelykwaardige state en dus die twee Republieke:

Gaat gij ontrouw zijn aan uw gegeven eerewoord (politieke verbond van 1889 en 1897)? Of gaat gij aan de wereld zeggen dat deze Staat hoewel klein en zwak, sterk genoeg is om trouw te zijn aan zijn eerewoord; dat gij beschouwt dat waar een Afrikaner in een goede zaak strijdt, daar is de neutraliteit van een ander Afrikaner een zonde tegen het Afrikanerdom? (Vrystaatse Volksraadsnotule 22/09/1899:16-24; vgl. Van der Merwe I 1921:250-256)

\footnotetext{
$14 \quad$ Vgl. Oberholster en Van Schoor (s.a.:14) vir 'n omskrywing van Steyn as 'n bittereinder van die bittereinders.

15 Steyn in 'n proklamasie in 1899 ter motivering van die Vrystaatse inval in die Kaapkolonie om die Britse opmars na die Republieke te stuit.
} 
Hiermee gee president Steyn blyke van 'n deurwrogte ${ }^{16}$ Christen-Afrikanerleier wat hom nie laat verlei of oorweldig, ook nie in hierdie omstandighede nie, deur die misbruikte opvatting dat mag reg is nie. Daarom sy dringende vraag aan die Vrystaatse Volksraad: “... gaat gij aan de wereld zeggen ...?" 17

In Oktober 1900 sê hy aan die burgers van die Waterberg in die ZAR dat staatkundige vryheid 'n gawe van God is (Rompel s.a.:83); 'n gawe wat beskerm moet word. Die president kies maatskap as die norm vir die verkeer tussen onafhanklike state in 'n Christelike volkereg - iets wat eers in die laaste helfte van die 20ste eeu uitvoerig ontwikkel sou word; 'n leer wat bou op die respek vir en strukturele gelykwaardigheid van state, groot en klein, sterk en swak, en nie evolusionisties aanvaar - soos imperialistiese Brittanje - dat mag reg is omdat dit gaan om die "survival of the fittest" nie (Wessels 1977:205; Strauss 2000:103).

In sy oorlogsmanifes van 11 Oktober 1899, die dag waarop die Anglo-Boereoorlog uitbreek, brei Steyn op hierdie siening uit. Volgens hom pleeg Brittanje met sy druk op die ZAR oor die stemreg van die "uitlanders" aan die Witwatersrand en sy doelbewuste afstuur op 'n oorlog in plaas van arbitrasie om die dispuut te besleg, onreg, skandelike geweld en inmenging. ${ }^{18}$ Deur die vertrapping van sy bestaande traktate waarin die onafhanklikheid van die Republieke erken word (die ZAR in 1852 by die Sandrivier en Republiek van die OranjeVrystaat in 1854 in Bloemfontein), verbreek Brittanje hiermee sy woord - op sigself 'n onChristelike daad - en verkrag hy daardeur die internasionale reg (Van der Merwe II 1921:1314; Oberholster \& Van Schoor s.a.:88-89).

Voor die laaste kongres van die Orangia-Unie op 7 Junie 1911 in Bloemfontein verwys MT Steyn na die misbruik van blanke prostitute of "die uitvaagsels van die maatskappy" aan die Rand deur swart en gekleurd. Vir hom is die muur van respek wat die Voortrekkers tussen hulle en die "Kleurlinge" (alle gekleurdes) opgebou het, hierdeur gesloop. Gekleurdes is ook in die Anglo-Boereoorlog deur sekere Britte gebruik om die blanke vrou met "ru geweld" na konsentrasiekampe te vervoer (Oberholster \& Van Schoor s.a.:178). Die oplossing lê nie in die galg nie, maar die heropbou van hierdie muur van respek. Respek kom nie deur gelykheid nie, maar 'n strenge regverdigheid. Die Unie moet gekleurdes egter nie soos vyande nie, maar vriende laat voel. As die Unie homself verdedig in 'n oorlog, moet die gekleurdes ook voel dat hulle bestaan op die spel is. "Ons" staan hier voor 'n afgrond, maar "moet ... toon dat ons nie hulle gelyke is nie, maar hulle vriende" (Oberholster \& Van Schoor sa:179). Steyn se houding impliseer dat gekleurdes regverdig hanteer moet word en dat gelykheid nie noodwendig

16 Steyn verklaar hierby dat hy die besluit om die politieke verbond na te kom, na “... dae van nadenke en nagte van gebed ..." geneem het (Oberholster en Van Schoor sa:81).

17 Kestell steun die president op hierdie punt. Wat hom betref was die Boere-ultimatum van 9 Oktober 1899 'n protes teen onreg en "dwingelandij”. Daarmee het 'n klein volkie aan 'n grote gesê: "Gij zijt groot en machtig, en gij wilt door uwe macht mij onderdrukken; maar ik verklaar hier voor de gansche wereld dat macht niet recht is; en ik trotseer u!'”(Kestell 1902:5-6). Frederik Rompel wat Steyn 'n tydlank op kommando vergesel het, praat met waardering van Steyn se idealistiese opvatting dat die koning/regerings reg en geregtigheid moet handhaaf. Dit is egter uit pas met die mode onder Europese politici (Van Schoor 2009:240).

18 President Steyn was daarvan oortuig dat die geskilpunte wat Brittanje vir 'n oorlog teen die ZAR aanvoer, ' $\mathrm{n}$ belediging vir die Christelike godsdiens en beskawing is - ' $\mathrm{n}$ misdaad teen die mensdom. Dit kon deur arbitrasie en nie oorlog nie, opgelos word. Hy maak die aanvaarding van die maatskapsfiguur in die volkereg dus afhanklik van beskaafde volke en state. Met sy doelbewuste afstuur op 'n oorlog met die Boerepublieke het Brittanje buite hierdie dampkring beweeg (Vrystaatse Volksraadsnotule 21/09/1899:10; 26:09:1899:113). 
regverdigheid is nie. Strenge regverdigheid in 'n ongelyke konteks moet/kan steeds regverdig wees én verhoudings bou ... ${ }^{19}$

Dit wil voorkom asof MT Steyn en die destydse Vrystaat die verhoudinge tussen blank en gekleurd nie ernstig bevraagteken het nie. Voor die Orangia-Unie spreek hy sy kommer uit dat hierdie saak oor die "afgrond" kan loop as die verhoudinge met gekleurdes skeefloop. Ongelukkig brei hy nie hierop uit nie en gee hy nie voorbeelde vir sy kommer nie. Dit is bekend dat die Vrystaat ná afloop van die oorloë teen die Basoetoe in 1868 en die Britse anneksasie van Basoetoeland in dieselfde jaar, tot die uitbreek van die Anglo-Boereoorlog in 1899, "volkome vrede binne sy eie grense geniet" het. Gekleurdes soos die Basoetoes, Mantatees, Barolong, Korannas en Griekwas het hulle in die Republiek van die Oranje-Vrystaat bevind, maar sonder volledige burgerregte (Oberholster, Van Schoor \& Maree 1954:18,43).

Die vraag is hoe ander kultuurgroepe as blanke groepe met 'n "beduidende" getal in die Vrystaat in MT Steyn se regeertyd hanteer is? Hoe MT Steyn vanuit sy Christelike visie op geregtigheid oor die behandeling van gekleurdes en anderskleurige werknemers geoordeel het? In die Vrystaatse politiek en Steyn se regeertyd van 1896-1902 en daarná was die klem op die Anglo-Boereverhouding waarskynlik so sterk dat die vraag na die toekoms van gekleurdes op die agtergrond geskuif is. Die verhouding met die Basoetoes en Griekwas is ná 1868 volgens die tradisionele tussenstaatlike verhoudinge tussen die Boere en swart volke gereël (Du Plessis s.a.:102,128), terwyl stemreg in die Republiek van die Vrystaat tot blankes beperk is. Daarby sou die Vrystaat volgens tradisie ruim van "inwonende" gekleurdes gebruik maak vir handearbeid (Oberholster, Van Schoor \& Maree 1954:18).

Voor die Vrystaatse Volksraad pleit Steyn in die laat 1890's vir die "groot beginsel" van 'n Christelike (Westers-georiënteerde) beskaafde vryheid, 'n beginsel wat hy in die volkstem by sy eie mense hoor én in die republikeins-demokratiese beginsel waarneem (Oberholster \& Van Schoor s.a.:68).

\section{MT STEYN' 'N BOEREPUBLIKEIN}

Hoewel MT Steyn die bestaan van die ZAR, die Vrystaat en ander state in Suider-Afrika as 'n gegewe aanvaar en die reg van elkeen op sy gebiedsintegriteit as 'n norm vir interstaatlike verkeer erken het, het daar by hom as Vrystaatse president die visioen van 'n verenigde SuidAfrika geleef. Daarvoor het hy een voorwaarde gestel: 'n verenigde Suid-Afrika moet 'n republikeinse Suid-Afrika wees. In hierdie visioen sou daar 'n volksmotief by Steyn meespeel: 'n staatkundig-verenigde Afrikanervolk met gelyke taalregte te midde van ander soos die Engelssprekendes - van die Kaap tot die Limpopo (Oberholster \& Van Schoor s.a.:11). Voor die Orangia-Unie in 1908 het hy weer die gebeure by die Slag van Graspan naby Reitz op 6 Junie 1901 opgehaal waar die bloed van 'n Kolonialer, 'n Vrystater en 'n Transvaler ineengevloei het (Oberholster \& Van Schoor sa:152). Deur die politieke verbond tussen die Vrystaat en die ZAR in 1897 wou Steyn die Afrikaner teen Britse imperialisme beskerm (Visser 1977:11). Al moes die Afrikaner sy republiek op politieke vlak met ander groepe deel, was dit vir Steyn 'n uitvloeisel van sy geneties-kulturele verwantskap: "De nauwere vereniging ligt in 't hart van 't volk, omdat wij één volk, één bloed zijn" (toespraak in Pretoria in 1896 verbatim in Van der Merwe I 1921:107). Tydens MT Steyn se verkiesing in 1896 verklaar hy dat as hy hom vir 'n ander staatsvorm as 'n republiek sou beywer, dit verraad teenoor "ons

$19 \quad$ Vgl. voetnoot 10. 
land" en die erfenis van "ons voorouers" sou wees (Van Schoor 1997:46). Vir Steyn was Afrikaners deur 'n gemeenskaplike kultuurstyl, gebruike en gewoontes aan 'n republiek verbind. Hy koppel staatkundige en kulturele eenheid onder Afrikaners wel aan hulle vrye assosiasie met 'n gemeenskaplike volkskultuur, maar soms - volks-idealisties - ook aan niegekose natuurwetmatige en determinerende Blut und Boden-bande van bloed (Oberholster \& Van Schoor sa:35).

Getrou aan homself moes MT Steyn hom ná 1902 teen die Britse Hoë Kommissaris verset. Volgens hom het Milner se regering in Transvaal die norm van geregtigheid aan almal op staatsbodem tot die reg van goudmyne op die bevoorregting en beskerming van die staat gereduseer (Oberholster \& Van Schoor s.a.:138). Hy het hierdie neiging aan kapitalisme as vyand van arbeid verbind; 'n seekat wat sy tentakels in elke vorm van arbeid inslaan (Van Schoor 1997:34).

Tydens die kongres van die Orangia-Unie in Maart 1908 sou Steyn sy pleidooi vir 'n verenigde, republikeinse Suid-Afrika herhaal (Oberholster \& Van Schoor s.a.:13). Vir Steyn was 'n unie vir die hele Suid-Afrika 'n idee wat by die leiers van die huidige vier kolonies op die subkontinent (Kaapkolonie, Natal, Vrystaat en Transvaal) geleef het, maar wat hy beskou het as 'n stap wat moes lei tot 'n republiek.

Steyn het ná sy verkiesing as president verwys na die volkstem as die "koningstem" waaraan meer erkenning in die grondwet van die Republiek van die Oranje-Vrystaat met bykomende bevoegdhede gegee moes word. Hoewel hy demokraties-republikeins oor staatsake gedink het, het hy die balans van magte in 'n staat as belangrik genoeg beskou om die "masjinerie behoorlik te laat werk". So nie, raak hierdie masjinerie uit orde. Dit is noodsaaklik om 'n middel te vind om hierdie ewewig - vir Steyn die balans van magte - te bewaar. Vir die Vrystaat het hy die middel in 'n beperkte referendum gevind. Daarmee bedoel hy nie 'n vetoreg nie, maar dat die volk deur 'n meerderheidstem kan verklaar dat byvoorbeeld haastige wetgewing of raadsbesluite in opgewondenheid geneem, nie van krag moet wees nie. Die beoogde referendum gaan nie oor enige maatreël van die Volksraad nie, maar beperkte sake: die verandering van die grondwet en besluite wat nie vooraf gepubliseer en nie van 'n dringende aard is nie. Dit lê 'n plig op elke burger om te besef dat sy eie welsyn sowel as die welsyn van die staat waarvan hy 'n burger is, van sy eie insette afhang. Steyn het na twee soorte referendums verwys: die referendum compulsatief en referendum facultatief. Eersgenoemde verwys na 'n referendum wat moet plaasvind en laasgenoemde na 'n referendum wat kan plaasvind. Daarmee wou Steyn besluite in die moderne Vrystaatse Republiek veiliger maak en die burgery vir die groot kwessies aktiveer. Die Volksraad wou hom egter nie volg nie (Oberholster \& Van Schoor s.a.:49-52; Van Schoor 1997:46-50).

In Pretoria in 1898 verbind Steyn "burgerlijke, beschaafde vrijheid" aan die volkstem as republikeinse beginsel. Gemeet aan die volkstem as die koningstem en oppergesag in 'n demokratiese republiek, neig Steyn na 'n liberaal-demokratiese aanpak van sake (Van Schoor \& Van Rooyen 1960:123-125). Aan die een kant bely die president die geldigheid van die Bybel in die totale lewe van die staat. Aan die ander kant gee hy aan die volkstem of die meerderheid van die volk die oppergesag. Daarmee vervang hierdie meerderheid die Here God as die opperste soewerein van die staat. Om die waarheid van hierdie gevolgtrekking te onderstreep, maak Steyn van ware volksregering 'n regering vir en deur die volk. Die volk, en nie die Here nie, sou dus oor die eerste en die laaste woord in die politiek beskik (Van Schoor \& Van Rooyen 1960:103, 112; Strauss 1996:563). Tog dui Steyn se opvatting oor die lewe daarop dat hy die Here God in alles wil dien. Boonop moes die Afrikaner volgens hom, die Afrikaner van die Afrikaners, oorlog tussen state met sy Bybel én sy geweer aanpak. 
Die Nasionale Vrouemonument met sy gedenknaald en gewyde atmosfeer, is op 16 Desember 1913 in Bloemfontein onthul. Die dryfkrag agter die Monument - ten opsigte van sy simboliek, ontwerp en gestalte - was die liggaamlik-geknakte, maar geestelik-kragtige bittereinder van die Boerebittereinders: MT Steyn. Dit was hy wat vanweë die "triomferende" martelaarskap van die Afrikanervrou en -kind in konsentrasiekampe "en elders ..." (vgl. die woorde op die gedenknaald, Volksblad 04/01/2014:7), hulle wat "tengevolge van den oorlog 1899-1902 zijn bezweken "20 (verdere woorde op die naald, Van Schoor 1993:2; Strauss s.a.:89), gesorg het dat die gedenknaald van 36,5 meter as 'n eenvoudige grafsteen in 'n gewyde omgewing die eerbied vir hierdie vroue en kinders lewend hou (Schoeman 1983:121). In sy hoofrede by die onthulling soos voorgelees deur Rocco de Villiers, sê hy onder meer:

Hierdie monument staan nie hier om enige iemand te pynig, of om 'n ewigdurende verwyt te wees nie, maar dit is hier geplaas uit reine piëteit. Dit is opgerig as 'n volk se hulde aan die gedagtenis van sy dierbares ...

Hierdie monument staan nie hier om haat aan te wakker nie, maar om liefde te bevorder, want ek sien die dag dat elke deel van die Suid-Afrikaanse volk, van watter oorsprong dit ook al mag wees, indien met 'n ware Suid-Afrikaanse gees besiel, die deugde deur hierdie monument verewig - as sy gemeenskaplike erfdeel sal beskou. (Oberholster \& Van Schoor s.a.:220)

Die oorhoofse boodskap op die Vrouemonument is: " $U w$ wil geschiede”. In die styl van 'n moderne Afrikanerheer, die vader van die Monument, MT Steyn, word hierdie Monument gewy "aan onze heldinnen en lieve kinderen", met 'n gedenknaald wat die besoeker wil herinner: "Ik zal u niet begeven" (dit is dan My wil wat geskied ...!) en "Voor Vryheid, volk en vaderland" (al moet julle 'n regstaat in die vorm van 'n republiek met ander deel). Dit is 'n monument wat die voortbestaan van die Afrikaner impliseer omdat hy as volk beskik is deur die voorsienige God soos vervat in die derde bede van die Onse Vader; 'n reël wat onvoorwaardelik en ongekwalifiseerd op die Monument aangebring is: "Laat U wil geskied" (Strauss sa:12-20).

MT Steyn sou die voorsitter en siel van die "werkende komitee" van die Nasionale Vrouemonument wees. Hy het reeds die naam "siel van die vryheidstryd" van 1899-1902 gedra. Die bedrag beraam vir die oprigting en onderhoud van die Monument was destyds $£ 15237$ (Van Schoor 1993: 6, 7). By die onthulling kon Steyn egter verklaar: "Het is opgericht niet alleen uit de rijkdom van de rijken, maar vooral uit de armoede der armen" (Van Schoor 1993:7).

MT Steyn se moderne Christen-Afrikanerleierskap sou egter breër loop as die Vrystaat, die Anglo-Boereoorlog en die Vrystaatse Afrikaner. Ná die ABO tree hy op as 'n erkende geestelik-kulturele leier én staatsman - 'n gemeenskapsleier - van Afrikaners in Suid-Afrika: daarvoor word enkele voorbeelde aangebied.

20 In die debatte wat soms rondom die Vrouemonument gevoer word, is politieke korrektheid in 'n moderne baadjie ook sigbaar. Die "en elders" sou dan dui op ander vroue en kinders - op ander plekke - as die Boervroue en -kinders wat gely het en geëer word. Vir die inisiatiefnemer van die Vrouemonument, Steyn, is die Monument egter opgerig as " $n$ volk se hulde aan die gedagtes van sy dierbares ...": die Hollands-Afrikaanse volk wie se taal die monument praat. Hierdie woorde op die monument kanselleer nie Emily Hobhouse se verwysing daarna as 'n "WORLD MONUMENT" vir vroue wêreldwyd nie; 'n monument wat fokus op die moed van vroue en om as vroue in die sake van gemeenskappe wêreldwyd gehuldig en geëer te word (Strauss s.a.:8). 


\section{MT STEYN 'N MODERNE AFRIKANERLEIER?}

In dieselfde trant waarin hy die kapitalisme as 'n geswore vyand en sieldodende kiem vir arbeid blootgelê het, sou Steyn op 10 Augustus 1912 die hoeksteen van die nuwe NG Kerk op Reitz lê:

In die Naam van die Drieënige God, Vader, Seun en Heilige Gees, verklaar ek hierdie steen wel en goed gelê. (Oberholster \& Van Schoor s.a.:131)

Die oudpresident se woorde het getuig van 'n sterk meelewing met die kerk. Hy wou materialisme met idealisme vervang. Sy oproep tot Christen-Afrikaners of "ons volk" was: "terug na die kerkbanke!" Hy het die invloed van die kerk op die gemeenskap beklemtoon en bygevoeg dat hierdie invloed nie dié van die predikant en kerkraad nie, maar van "ons" is. "Ons" moet die hande uitsteek, nie stene vir brood gee nie en "toesien dat dorstige siele geles word". As 'n Christen-Afrikaner kon Steyn nie nalaat om te sê dat Reitz die eerste kerk is waarvan 'n seun van die land die argitek is en hy wat Steyn is, die hoeksteen lê nie (Oberholster \& Van Schoor s.a.:132). Die oudpresident was boonop 'n simbool van 'n noue verhouding tussen die Republiek van die Oranje-Vrystaat en die NG Kerk in die Vrystaat en 'n belydende lidmaat van die NG Kerk in Bloemfontein (Van der Merwe II 1921:354-355; Schoeman 1983:28-29).

Vroeër, by die opening van die Meisieskool Oranje waar Steyn stigter en voorsitter van die Kuratorium was, het hy opnuut sy vertroue in die vroue as, dit is sy eie woorde, "onze heldinnen" in die "volkslewe" en Christelike skole getoon. Steyn wou 'n vrye Christeliknasionale skool stig waar onderwyseresse vir die Afrikanerkind opgelei word; 'n skool wat beantwoord aan die moderne eise vir 'n goeie, deeglike opleiding en waar dogters toegerus word vir die lewe; 'n skool wat nóg Engels, nóg Hollands, maar in die "suiwerste sin" van die woord Afrikaans is; 'n niesektariese, Christelike skool waar die Bybel die ereplek kry as die "enigste gids" van die lewe. Die skool moet vroue lewer met liefde vir hulle volk, taal en God. Hulle moet soos die duisende Afrikaanse vroue en kinders in Britse konsentrasiekampe van 1900-1902 - later staan hierdie woord op die Vrouemonument - "heldinne" wees en 'n eer vir hulle alma mater (Oberholster \& Van Schoor s.a.: 109-111).

Steyn se gebruik van die woord "heldinne" op talle plekke, herlei hierdie woord op die Vrouemonument na hom as die vader van die Monument. 'n Verbindingslyn tussen dié woord en Steyn as die oorsprong daarvan is aantoonbaar. Hy het as 'n Boere-gentleman by voorkeur van die vroue wat volhardend in die oorlog gely het, as heldinne gepraat (Strauss s.a.:13,14). Hy wou 'n Afrikaanse Meisieskool Oranje op die Christelike waarhede van die algemene Christelike kerk van die eerste eeue vestig. Soos die Nederlandse Geloofsbelydenis wou Steyn die Afrikaanse dogters van die skool bind aan die algemene Christendom en God Drie-enig - Steyn se Driemaal Heilige God - én verlossing as die vrug van God se genade (NG KerkUitgewers 1982:9-38).

By die opening van 'n spin- en weefskool op Bethlehem op 23 November 1907, deel die oudpresident komplemente uit aan Afrikaners wat as mense, in Gods koninkryk, hard werk. Op 'n vraag wanneer die Afrikaners selfstandig was, antwoord hy nostalgies: toe hulle "eenvoudig van leefwyse, self alles gefabriseer het wat hulle in die huis nodig gehad het". Die vroue kon pronk met selfgemaakte rokke en manne met soortgelyke velskoene. 'n ChristenAfrikaner steek nie lyf weg nie. Hy werk hom uit 'n probleem uit (Oberholster \& Van Schoor s.a.:116-117)! 
Toe Steyn se skriftelike uitnodiging aan Kestell om by hom op kommando aan te sluit deurkom, het die dominee dadelik "op reis" gegaan. Hy kon nie wag nie (Kestell 1902:172). In die diktering van sy ervaring van die oorlog aan Tibbie Steyn in sy soort Nederlands, verwys die oudpresident ook na die keer toe hy die toneel van die vredesamesprekings in Mei 1902 weens ernstige siekte moes verlaat.

Toen ik 'n entjie weg was gereden, liep ds. Kestell het rijtuig achterna om mij te groeten. Hem had ik lief gekregen als 'n broeder ... (opgeneem in Van der Merwe II 1921:101)

\section{SLOT}

MT Steyn as 'n bittereinder was nie net taakgeoriënteerd en -gemotiveerd nie. Hy was ook menslik met 'n aanvoeling vir mense en hulle verantwoorde regte. Steyn was 'n ewewigtige, moderne Christen-Afrikanerleier.

Steyn is met groot agting die bittereinder van die bittereinders genoem. Hy kon vasbyt met 'n "dogged courage" en meer as 20000 Boerebittereinders in die Anglo-Boereoorlog emosioneel-fisies met hom meeneem. As 'n sleutelrolspeler in die oorlogspoging van die Vrystaatse Republiek het hy met woord en daad ' $n$ inspirerende faktor in die twee Boererepublieke se verset teen Britse imperialisme geword. Die Britse opperbevelhebber, lord Kitchener, se opmerkings oor Steyn kort voor vrede in 1902 getuig daarvan. Kitchener het Steyn gerespekteer en was getuie van sy oorreding van weifelende Transvalers en ander Boere, by verskeie geleenthede, om die stryd voor te sit. Hoewel moeilik meetbaar, glo historici dat MT Steyn se fisiese teenwoordigheid die Boere aangespoor en die Anglo-Boereoorlog waarneembaar verleng het. Sommige Britse imperialiste se verwagte drie maande het tweeen-dertig maande geword. Die gehuldigde helde van die oorlog - in Afrika én Europa - was Boerebittereinders soos Steyn, De Wet en De la Rey. MT Steyn se vrees dat 'n Britse oorwinning tot selfveragting onder die Boere kan lei is, te danke aan Steyn se inspirerende leierskap, nie bewaarheid nie. Inteendeel, die Anglo-Boereoorlog was 'n bron van inspirasie vir die Afrikaner van die twintigste eeu.

Daar is ook 'n ander kant in Steyn se persoonsmondering. Op Vader Kestell se weiering toe MT Steyn hom in Junie 1900 'n veggeneraalskap aanbied, het die president erkennend en versoenend reageer. Hy word 'n pastor vir die pastor en 'n mens wat die geroepe take en menings van ander erken.

Wonderlik ... Dominee om jou by ons te kan hê. U het my hoogste agting vir u besluit. Ek bewonder u daarvoor, maar van vandag af beskik ek in De Wet oor 'n generaal duisend op die krygsakker en in u, Dominee, oor 'n generaal duisend op die geestelike akker. (Van Schoor 1992:89)

Uit die Anglo-Boereoorlog het MT Steyn as 'n gerespekteerde leier van Afrikaners gekom; 'n Afrikaner wat 'n groot rol by die Nasionale Konvensie wat sou lei tot die Unie van SuidAfrika in 1910, gespeel het. Sy mening was gerespekteer en gesog onder Afrikaners én by ander. Hy was 'n gewilde spreker by talle geleenthede.

In sy laaste toespraak, tydens sy dood op 28 November 1916 voor die Oranje Vrouevereniging in Bloemfontein, het hy ook na die Rebellie van 1914-1915 onder Afrikaners verwys. Hy het gepraat van die Helpmekaarfonds wat deur die Rebelle gestig is om vir die fisiese skade wat hulle veroorsaak het, te vergoed. Steyn was 'n aktief-belydende Christen én Afrikanervoorman wat sy mense Christelik-eties kon bind. 
Die Helpmekaar is die enigste liggaam in die wêreld waar ' $n$ volk wat in opstand was, saamgespan het om die skade te vergoed en selfs deur hulle opponente gehelp is. Die man wat teen so 'n beweging gewerk het, sou geen vriend van die volk gewees het nie (Oberholster \& Van Schoor s.a.:222; Scholtz 1944:117).

MT Steyn was 'n moderne Christen-Afrikanerleier met 'n veelsydigheid wat sy mense agter hom kon verenig.

\section{BIBLIOGRAFIE}

De Gouvernements Courant OVS, 27/12/1895.

De Wet, CR. 1959. Die stryd tussen Boer en Brit. Kaapstad: Tafelberg (in Afrikaans vertaal deur JJ Human).

Du Plessis, JS. sa., President Kruger aan die woord. Bloemfontein: Sacum.

Giliomee, H. 2003. The Afrikaners. Biography of a people. Kaapstad:Tafelberg.

Giliomee, H. s.a. 'n Ideale gemenebes in Afrika-omstandighede. Die Vrystaatse Republiek 1854- 1900. Sl:sa ISSN 1995-5928.

Kestell, JD. 1902. Met de Boeren-commando's. Mjne ervaringen als veldprediker. Amsterdam/Pretoria: Höveker \& Wormser.

Koorts, L. 2004. DF Malan die opkoms van Afrikanernasionalisme. Kaapstad: Tafelberg.

Kruger, DW. 1972 (hoofredakteur). Suid-Afrikaanse Biografiese Woordeboek II. Kaapstad: Tafelberg.

Loe, E. 1985. To the bitter end. London: Butler \& Tanner.

Meintjes, J. 1969. President Steyn. Kaapstad: Nasionale Boekhandel.

NG Kerk (NGK) 2012. Jaarboek van die Nederduitse Gereformeerde Kerke. Wellington: Bybelmedia.

NG Kerk-Uitgewers 1982. Ons glo... Die drie formuliere van Eenheid en ekumeniese belydenisse. Kaapstad: NG Kerk-Uitgewers.

Oberholster, JJ \& Van Schoor, MCE. s.a. President Steyn aan die woord. Bloemfontein: Sacum.

Oranje Vrijstaat (OVS). 1899. Volksraadsnotule 21/09/1899; 22/09/1899; 26/09/1899.

Pakenham, T. 1979. The Boer War. Johannesburg: Jonathan Ball.

Raath, AWG. 2012. Onthou. Brandfort: Kraal.

Reynolds, C. 2013. Konsentrasiekampsterftes gedurende die Anglo-Boereoorlog 1899-1902. Brandfort: FAK.

Schoeman, K. 1983. In liefde en trou. Kaapstad: Human \& Rousseau.

Scholtz, GD. 1944. Dr. Nicolaas Johannes van der Merwe 1888:1940. Johannesburg: Voortrekkerpers.

Strauss, PJ. s.a. Uitdrukkings op die Nasionale Vrouemonument geweeg. Bloemfontein: Drufoma.

Strauss, PJ. 1996. Aantekeninge oor lewensbeskoulike aspekte in die openbare standpunte van president M.T. Steyn 1896-1902. Ned Geref Teologiese Tydskrif 37/558-571.

Van der Merwe, NJ. 1921. Marthinus Theunis Steyn. 'n Lewensbeskrywing I en II. Bloemfontein: Nasionale Pers.

Van Schoor, MCE. 1992. John Daniel Kestell. Bloemfontein: NG Sendingpers.

Van Schoor, MCE. 1993. Die Nasionale Vrouemonument. Bloemfontein: Oorlogsmuseum van die Boererepublieke.

Van Schoor, MCE. 1997. 'n Bittereinder aan die woord. Marthinus Theunis Steyn. Bloemfontein: Oorlogsmuseum van die Boererepublieke.

Van Schoor, MCE. 2009. Marthinus Theunis Steyn - regsman, staatsman, volksman. Pretoria: Protea.

Van Schoor, MCE \& Van Rooyen, JJ. 1960. Republieke en Republikeine. Bloemfontein: Nasionale Boekhandel.

Visser, 1977. President M.T. Steyn se rol in die Anglo-Boereoorlog. Bloemfontein: UOVS ongepubliseerde MA-verhandeling.

Volksblad 04:01:2014, 7.

Wessels, FJH. 1977. Ongeloof en wêreldgebeure. Strauss, DFM. (red). Woord en Wetenskap. Bloemfontein: VCHO, pp. 202-211. 